\title{
Review
}

\section{Toxoplasmosis in humans and animals in Saudi Arabia: A systematic review}

\author{
Khalil Mohamed ${ }^{1}$ \\ ${ }^{1}$ Department of Epidemiology, Faculty of Public Health and Health Informatics, Umm AL Qura University
}

\begin{abstract}
Introduction: The causative agent of toxoplasmosis is Toxoplasma gondii (T. gondii); an intracellular obligate parasite causes abortion in humans and animals. The review aims to clarify the situation of the disease in humans and animals in different parts of the country so that data will be available for any future work regarding the control of the disease.

Methodology: All humans and animal research studies published in the last 18 years between 2000 and 2018 in Saudi Arabia were targeted, including prevalence or seroprevalence of $T$. gondii infection or antibodies. The searched strategy included human or pregnant women or children as well as animals or any particular species.

Results: The result showed that approximately one-third of the population in Saudi Arabia had IgG seropositivity, and 6.4\% had IgM seropositivity. Moreover, the disease was widespread in almost all the regions except AL- Jouf, where no data published. The prevalence of the chronic infection was high in sheep in Riyadh 68\%, and the prevalence of acute was found in Najran $19 \%$ in sheep, goats, and camels. Conclusions: The current article showed the importance of the disease in Saudi Arabia for both humans and animals. The educational programs should be established to impart people to avoid the infection by the parasite.
\end{abstract}

Key words: Toxoplasmosis; prevalence; risk factors; Saudi Arabia.

J Infect Dev Ctries 2020; 14(8):800-811. doi:10.3855/jidc.12648

(Received 10 March 2020 - Accepted 28 June 2020)

Copyright (C) 2020 Mohamed. This is an open-access article distributed under the Creative Commons Attribution License, which permits unrestricted use, distribution, and reproduction in any medium, provided the original work is properly cited.

\section{Introduction}

The causative agent of toxoplasmosis is Toxoplasma gondii (T. gondii) an intracellular obligate parasite causes abortion in human and animals [1]. During different periods of the parasite life cycle, individual parasites convert into various cellular stages. These stages include the sporozoites, bradyzoites, and tachyzoites [2]. The parasite's life cycle consists of two stages: a sexual stage that appears in cat and asexual stages which occur in all warm-blooded animals, including humans [3]. The parasite can affect both humans and animals, including camels, cattle, sheep, goats, poultry, and wild animals [4]. Lymphadenitis is the most common clinical form of the disease [5-8].

In contrast, the effect of the disease during pregnancy depends on the time of infection; for example, a pregnant woman infected in the third trimester often there will be asymptomatic diseases to new-born [9]. The effect of the parasite in animals may lead to economic impact; in sheep, the infection may cause fetal death and mummification, early embryonic death and resorption, neonatal death, stillbirth, and abortion [10]. The parasite does not pass from person to person with direct contact, but vertical transmission may appear from mother to her fetus. Intermediate hosts can get the infection via horizontal transfer, including different routes such as contaminated water or food [11].

As in the case of most other protozoa, the prevalence of $T$. gondii is higher in developing areas of the world. However, T. gondii is one of the few protozoans, which has maintained a significant prevalence in developed countries such as the United States [12].

The diagnosis of toxoplasmosis still depends on the detection of different types of antibodies, which each of them has a different interpretation. Detecting IgM in the blood sample of the patient using the ELISA technique means the infection in the acute phase while found IgG means past infection [13].

In pregnant women, several procedures should be followed to prevent them from getting the infection, mainly contacting a cat or the area where it lives. The crucial thing is washing hands and good personnel hygiene [14].

In Saudi Arabia, there were numerous studies done to estimate seroprevalence, and the majority of the studies were conducted among pregnant women. The current work implemented to clarify the situation of the disease in Saudi Arabia besides explaining which the target group of people needs to look for them and to 
know where and how the plan should be conducted to fight the disease.

\section{Prevalence of toxoplasmosis in human}

The estimation is done by WHO confirmed that approximately $30 \%$ to $50 \%$ of people worldwide had an infection with $T$. gondii [15]. Most of the more than one-third of the world's human population who are infected with $T$. gondii remain asymptomatic because the immune system usually keeps the parasite from causing illness. Chronic, typically lifelong, infection with Toxoplasma that is not accompanied by overt clinical symptoms of toxoplasmosis disease is termed latent toxoplasmosis. In contrast, chronic infection associated with continuous or recurrent clinical symptoms is termed chronic toxoplasmosis [16]. The prevalence of toxoplasmosis in the US was declining, although $14 \%$ of people still seropositive [17] with one million new cases each year, resulting in about twenty thousand cases of retinal infection [18] and 750 death cases [19]. The highest prevalence is found in Latin America, parts of Eastern/Central Europe, the Middle East, and parts of South-East Asia and Africa [20].

Low seroprevalence (10 to 30\%) has been observed in North America, in South East Asia, in Northern Europe, and Sahelian countries of Africa. Moderate prevalence (30 to 50\%) has been found in countries of Central and Southern Europe, and high prevalence has been found in Latin America and tropical African countries [21].

The prevalence rate of toxoplasmosis in Asian countries was found to be between 23 to $45 \%$ in pregnant women in Malaysia, 1.4 to $21.7 \%$ in Thailand, and up to $17.2 \%$ in Singapore [22]. Even though toxoplasmosis is a disease distributed worldwide, there is rare information on the prevalence and epidemiology of the disease in the Arabian Peninsula countries [23]. In UAE, the seropositivity was the lowest in the Arabian Peninsula (22.9\%) [24]. In Qatar, a study that examined seropositivity in the general population demonstrated a rate of $29.8 \%$ [25]. In Kuwait, as one of the Arabs peninsula countries, the seropositivity rate was highest (45.7\%) [26].

\section{Prevalence of toxoplasmosis in animals}

The disease of toxoplasmosis is critical in meatproducing animals because these animals are still the primary source of infection to humans. The infection can be reduced by following some hygienic procedures and intensive farm management. The seropositivity of the disease in sheep in Europe may reach 89\% [27], while the prevalence rate in goats in Europe may reach
$77 \%$ [28]. Infection of T. gondii in cattle and the prevalence still was the kind of debate, but the recorded data confirmed that the prevalence rate might reach 92\% in Europe [1].

\section{Risk factors associated with toxoplasmosis} Age

some studies associated the infection of $T$. gondii with the age of the target groups, particularly in Arab countries $[29,30]$. One study in Egypt found that the disease increased with age [31]. Opposing these studies, some studies in pregnant women in China found no relationship between infections with $T$. gondii and age [32].

Gender

National population based-surveillance done in the USA found that the prevalence of toxoplasmosis in men was higher than in women [33]. Some other studied showed no gender-related with the $T$. gondii infection $[34,35]$.

\section{Location}

In the Arabic countries' area and the Middle East countries, the prevalence of toxoplasmosis was different according to the area. Previous studies were done in the Arabian Peninsula area, shown different seropositivity of toxoplasmosis, which ranges between $22.9 \%$ to $58.2 \%$ [36-38]. In the Sham area, the prevalence of toxoplasmosis ranges between $23.4 \%$ to $62 \%$ among pregnant women $[39,40]$. In the Wadi-AlNile area, the seroprevalence of toxoplasmosis in Egypt in pregnant women showing the highest prevalence in this region, which ranges between $46.1 \%$ and reached $62.1 \%[41,42]$ In Sudan, the seroprevalence in pregnant women was $34.1 \%$ reported in 2003 , while the prevalence rate reached $58.3 \%$ in aborted women $[43,44]$. In the Maghreb area, the prevalence of toxoplasmosis was higher compared with other regions. The record showed prevalence between $47 \%$ to $64 \%$ in Tunisia, Algeria, Morocco, and Libya [45-47].

\section{Contact with Cats}

Cats play a crucial role in transmitting the infection as the definitive host. In the literature, there was colossal work done. Some of these workers found a strong relationship between direct contact with a cat and the infection; other studies found no association between direct contacts with a cat and get an infection $[44,48]$. In general, living with domestic cats and exposure to their feces may increase the chance of getting the disease. 
Raw Meat

In the majority of the epidemiological studies, researchers found that eating raw or undercooked meat, maybe the first source of the infection by $T$. gondii [4951]. Some other studies found an association between getting an infection with $T$. gondii and cutting meat [52].

Contaminate Hands

Transmission can be done via contamination of hands by exposure to the feces of cat containing oocysts when cleaning the cat's litter or exposure to bradyzoites when cutting the raw meat [53]. Therefore, contaminated hand plays a significant role in the transmission of the parasite by different forms.

\section{Drinking Unboiled Milk}

Consumption unboiled milk or milk products containing tachyzoite of $T$. gondii still play the role of infection as the tachyzoite of the parasite resistant the trypsin and pepsin $[54,55]$.

\section{Contact with other Animals}

Some animals such as goats, sheep, and pigs are more susceptible to infection by $T$. gondii and may harbor the bradyzoite of the parasite for life [56,57]. Thus, the infection will transmit to humans by eating the raw meat extracting from these animals or by direct contact of raw meat contains the tissue cyst.

\section{Contact with Soil or working in the garden}

The oocyst of $T$. gondii can survive in the soil for life. An individual who in direct contact with soil or children who are playing in the earth may get the infection via contaminated or dirty hands [58].

\section{Blood transfer and organ transplantation}

This is another example of a person-to-person route for transmission besides congenital toxoplasmosis. Although the parasite survival in the bloodstream for a short period but the transmission via blood still can be happened even is rare $[59,60]$.

\section{Socio-economic Impact}

The effectiveness of infection with $T$. gondii to mother and fetus during pregnancy may be stiff. For instance, there was no effective vaccine available and no strategic plan to control the disease in pregnant women or children in developing countries. The socioeconomic impact of the disease in these countries will be at high cost in humans and animals, mainly when the abortion occurs [61].

\section{Methodology}

Related data and studies on prevalence and risk factors of $T$. gondii infection and toxoplasmosis in humans and animals were researched in Saudi Arabia using Pub-med, Scholar-Google, ProQuest Central, Science Direct, Web of Science, Scopus, Springer, and Taylor \& Francis as seen in Table1 between 2000 and 2019.

The critical fundamentals used for reviewing included humans or animals for review questions and the prevalence of $T$. gondii for the outcome. The probable elements used for searching included: (1) Prevalence of Toxoplasma gondii infection in human or pregnant women or children in Saudi Arabia. (2) Seroprevalence of Toxoplasma gondii infection in human or pregnant women or children in Saudi Arabia. (3) A cross-sectional study of Toxoplasma gondii in human or pregnant women or children in Saudi Arabia. (4) Detection of Toxoplasma gondii in human or pregnant women or children in Saudi Arabia. (5) Prevalence of Toxoplasma gondii infection in Farm animals or slaughterhouse animals in Saudi Arabia. (6) A cross-sectional study of Toxoplasma gondii in animals or farm animals or slaughterhouse animals in Saudi Arabia. (7) Detection of Toxoplasma gondii in animals or farm animals or slaughterhouse animals in Saudi Arabia.

Table 1. The articles search from different resources.

\begin{tabular}{|c|c|c|c|c|c|c|}
\hline Serial No. & Publisher & 2000-2004 & 2005-2009 & 2010-2014 & 2015-2019 & Total \\
\hline 1 & Pub-Med & 0 & 0 & 5 & 1 & 06 \\
\hline 2 & Google Scholar & 2 & 2 & 14 & 8 & 26 \\
\hline 3 & ProQuest central & 0 & 0 & 5 & 1 & 06 \\
\hline 4 & Science Direct & 0 & 0 & 0 & 2 & 02 \\
\hline 5 & Web of Science & 1 & 0 & 5 & 1 & 07 \\
\hline 6 & Scopus & 0 & 0 & 6 & 3 & 09 \\
\hline 7 & Springer & 0 & 0 & 1 & 0 & 01 \\
\hline 8 & Taylor and Francis & 0 & 0 & 1 & 1 & 02 \\
\hline 9 & Others & 0 & 1 & 7 & 2 & 10 \\
\hline & Total & 03 & 03 & 44 & 19 & 69 \\
\hline
\end{tabular}


Figure 1. Seroprevalence of chronic toxoplasmosis in Saudi Arabia by administrative region.

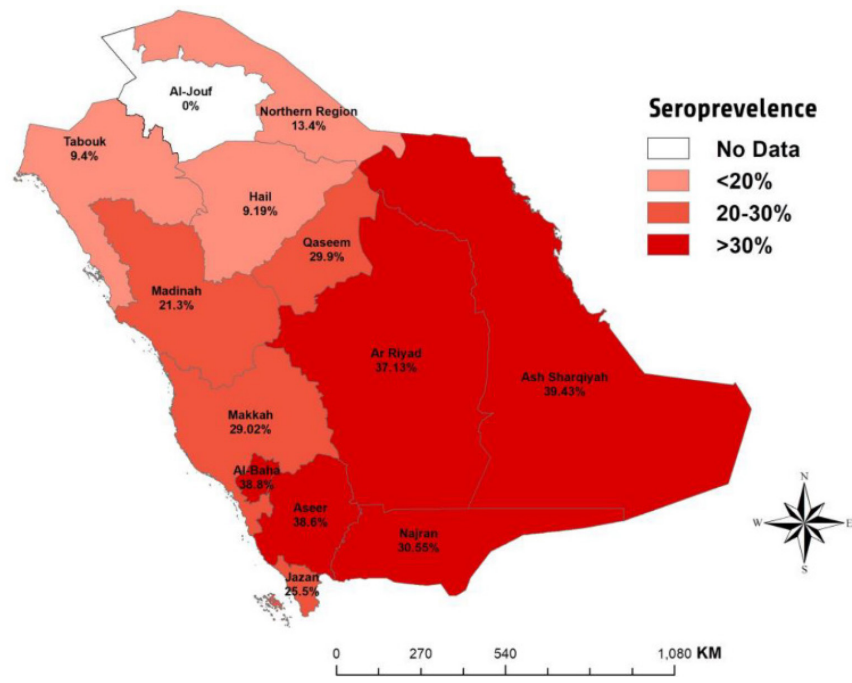

All human and animal research studies published in the last 18 years between 2000 - 2018 in Saudi Arabia were targeted, including prevalence or seroprevalence of $T$. gondii infection or antibodies. The searched strategy included human or pregnant women or children as well as animals or any species in particular. Different excluded criteria were approved to select suitable studies. These criteria included: 1) Descriptive studies, short commination, reviews, case-report, letter to the editor, or other studies did not show original data. 2) Studies did not include our target group. 3) Studies limited to the use of experimental infection by $T$. gondii. 4) Studies not done in Saudi Arabia.
Table 2. Seroprevalence of acute toxoplasmosis in different areas in Saudi Arabia (2000-2019).

\begin{tabular}{lc}
\hline Area & Seroprevalence rate (IgM) \\
\hline Middle area & $6.4 \%$ \\
Northern area & $0.44 \%$ \\
Western area & $2.45 \%$ \\
Eastern area (Ash Shargiyah) & $17.7 \%$ \\
Southern area & $4.82 \%$ \\
\hline
\end{tabular}

\section{Results}

\section{Prevalence of toxoplasmosis in KSA}

The seroprevalence of toxoplasmosis was estimated in different populations in Saudi Arabia between 2000 and 2019, according to previous publications done. Various studies have shown that IgG seropositivity of toxoplasmosis in Saudi Arabia about 29.52\%, while the IgM seropositivity of toxoplasmosis about $6.4 \%$. The IgG seropositivity of the infection in various regions, ranging from $9.13 \%$ in the Hail region to $39.43 \%$ in the Eastern region (Figure 1). The IgM seropositivity in the various regions ranging from $0.44 \%$ in the northern region to $17.7 \%$ in the eastern region (Table 2). Both IgG and IgM seropositivity increased in northern areas to the southern areas.

\section{Seroprevalence of toxoplasmosis in pregnant women}

Toxoplasmosis is a significant disease, particularly in pregnant women and their infants. Therefore several studies are done in this target group. The IgG seropositivity of toxoplasmosis in pregnant women in Saudi Arabia, ranging from $8.57 \%$ in Hail to $51.4 \%$ in Al Ahsa. The overall IgG seropositivity of toxoplasmosis in pregnant women about 29.6\%;

Table 3. Seroprevalence of Toxoplasma gondii infection among pregnant women.

\begin{tabular}{|c|c|c|c|c|c|}
\hline City & $\begin{array}{l}\text { Sample } \\
\text { size }\end{array}$ & Assay & $\begin{array}{c}\text { Prevalence rate } \\
\text { IgG\% }\end{array}$ & $\begin{array}{c}\text { Prevalence rate } \\
\text { IgM\% }\end{array}$ & References \\
\hline Riyadh & 2176 & IHT, ELISA IgM & $38.0 \%$ & $0 \%$ & {$[76]$} \\
\hline Riyadh & 203 & ELISA IgG and IgM & $32.5 \%$ & $6.4 \%$ & [77] \\
\hline AD-Dawadimi & 461 & ELISA IgG and IgM & $40.9 \%$ & $0 \%$ & {$[78]$} \\
\hline Hail & 100 & ELISA IgG and IgM & $8.57 \%$ & - & [79] \\
\hline Jazan & 195 & ELISA IgG and IgM & $20.0 \%$ & $6.2 \%$ & [23] \\
\hline Khamis Mushait and Abha & 487 & ELISA IgG and IgM & $38.8 \%$ & $6.2 \%$ & [80] \\
\hline Jazan & 226 & ELISA IgG and IgM & $14.6 \%$ & $1.3 \%$ & [81] \\
\hline Aseer & 137 & ELISA IgG and IgM & $38.6 \%$ & $6.5 \%$ & {$[82]$} \\
\hline Qassim & 586 & ELISA IgM & - & $1.2 \%$ & [83] \\
\hline Makkah & 326 & ELISA IgG and IgM & $21.2 \%$ & $1.2 \%$ & [84] \\
\hline Almadinah & 150 & $\begin{array}{c}\text { Rapid Test and ELISA IgG and } \\
\text { IgM }\end{array}$ & $21.3 \%$ & $0 \%$ & {$[85]$} \\
\hline Makkah & 926 & ELISA IgG & $35.6 \%$ & - & {$[86]$} \\
\hline Makkah & 197 & ELISA IgG and IgM & $29.4 \%$ & $5.6 \%$ & [87] \\
\hline Arar & 340 & IHAT and ELISA IgG and IgM & $13.5 \%$ & $0.6 \%$ & {$[88]$} \\
\hline Al-Khobar & 175 & Toxo IgG and IgM & $39.4 \%$ & $0.57 \%$ & [89] \\
\hline Al Ahsa & 554 & ELISA IgG and IgM & $51.4 \%$ & $6.1 \%$ & {$[90]$} \\
\hline Hail & 6,076 & ELISA IgG and IgM & $9.8 \%$ & $0.58 \%$ & [91] \\
\hline
\end{tabular}


however, the overall IgM seropositivity of toxoplasmosis in pregnant women about 3.0\% (Table $3)$.

\section{Seroprevalence of toxoplasmosis in other groups}

Other groups, including women other than pregnant, men, students, and blood donors, were being targeted for several research studies to clarify the situation of the diseases in these target groups. The results obtained from different studies shown that the IgG seropositivity of toxoplasmosis ranging from $4.7 \%$ in students in Jeddah to $41.9 \%$ in women, men, and infants in Jazan (Table 4). Whereas the prevalence of $\operatorname{IgM}$ seropositivity of toxoplasmosis ranging from $0 \%$ in different target groups, particularly in women and students in different areas to $46.3 \%$ in women in $\mathrm{Al}$ Ahsa, as shown in Table 4.
Toxoplasmosis as an opportunistic infection

The parasite of $T$. gondii plays an opportunistic infection in different patients of other diseases, particularly disease caused immunosuppression such as cancer, AIDS, and so on. In Saudi Arabia, several studies were done; aim to study the prevalence of toxoplasmosis among these target groups. The result recorded showed a high IgG seropositivity found in some patients in Jeddah $61.4 \%$, and the less prevalence rate observed patients with AIDS in Makkah 21.3\% (Table 5). The IgM seropositivity recorded a high in AIDS patients in Makkah 12.5\% and no positive results recorded in diabetic patients in Makkah or patients with major depression disorders in Makkah area (Table 5).

Table 4. Seroprevalence of Toxoplasma gondii infection among other populations.

\begin{tabular}{|c|c|c|c|c|c|c|}
\hline City & Target group & Sample size & Assay & $\begin{array}{l}\text { Prevalence } \\
\text { rate IgG \% }\end{array}$ & $\begin{array}{l}\text { Prevalence } \\
\text { rate IgM \% }\end{array}$ & References \\
\hline Tabuk & Student & 180 & ELISA IgG and IgM & $9.4 \%$ & $0 \%$ & {$[92]$} \\
\hline Najran & $\begin{array}{l}\text { Male, Female, and } \\
\text { Children }\end{array}$ & 210 & ELISA IgG & $31.9 \%$ & - & [93] \\
\hline Najran & Women & 96 & IHA and ELISA IgG and IgM & $29.2 \%$ & $3.1 \%$ & [94] \\
\hline Jazan & $\begin{array}{l}\text { Women, men, and } \\
\text { infants }\end{array}$ & 124 & LAT, IHA and ELISA & $41.9 \%$ & $5.65 \%$ & {$[95]$} \\
\hline Jeddah & Student & 127 & ELISA IgG and IgM & $4.7 \%$ & $0 \%$ & {$[96]$} \\
\hline Makkah & Blood donors & 220 & ELISA IgG and IgM & $19.5 \%$ & $0 \%$ & [97] \\
\hline Makkah & Male and female & 924 & ELISA IgM & $24.8 \%$ & $0.3 \%$ & [98] \\
\hline Rafha & Women & 162 & ELISA IgG and IgM & $12 \%$ & $0 \%$ & [99] \\
\hline Rafha & Women & 508 & ELISA IgG and IgM & $14.6 \%$ & $0 \%$ & {$[100]$} \\
\hline Al Ahsa & Women & 160 & $\begin{array}{c}\text { ELISA IgG and IgM and IgG } \\
\text { avidity }\end{array}$ & $27.5 \%$ & $46.3 \%$ & {$[101]$} \\
\hline Eastern & Male and female & 1464 & MEIA IgG and IgM & $25.0 \%$ & $5 \%$ & {$[102]$} \\
\hline
\end{tabular}

Table 5. Seroprevalence of Toxoplasma gondii as an opportunistic infection.

\begin{tabular}{|c|c|c|c|c|c|c|c|}
\hline Region & City & Target group & $\begin{array}{l}\text { Sample } \\
\text { size }\end{array}$ & Assay & $\begin{array}{l}\text { Prevalence } \\
\text { rate IgG \% }\end{array}$ & $\begin{array}{l}\text { Prevalence } \\
\text { rate IgM \% }\end{array}$ & References \\
\hline Qassim & Qassim & Cancer patient & 137 & ELISA IgG and IgM & $29.9 \%$ & $0.7 \%$ & [103] \\
\hline Makkah & Makkah & $\begin{array}{l}\text { AIDS patients and } \\
\text { control }\end{array}$ & 80 & ELISA IgG and IgM & $21.3 \%$ & $12.5 \%$ & [104] \\
\hline Makkah & Makkah & Diabetic patients & 90 & ELISA IgG and IgM & $43.3 \%$ & $0 \%$ & {$[105]$} \\
\hline Makkah & Jeddah & Patients & 70 & $\begin{array}{c}\text { ELISA IgG and } \\
\text { PCR }\end{array}$ & $61.4 \%$ & - & {$[106]$} \\
\hline Jazan & Jazan & $\begin{array}{c}\text { Neuropsychiatric } \\
\text { patients }\end{array}$ & 162 & ELISA IgG and IgM & $35.8 \%$ & $6 \%$ & {$[107]$} \\
\hline Riyadh & Riyadh & $\begin{array}{l}\text { Glucose-6- } \\
\text { phosphate } \\
\text { dehydrogenase } \\
\text { deficiency }\end{array}$ & 53 & ELISA IgG and IgM & $58.8 \%$ & $1.9 \%$ & [108] \\
\hline Makkah & $\begin{array}{l}\text { Makkah, } \\
\text { Jeddah, and } \\
\text { Taif }\end{array}$ & $\begin{array}{l}\text { Schizophrenia and } \\
\text { major depression } \\
\text { disorder }\end{array}$ & 177 & ELISA IgG and IgM & $\begin{array}{l}31.75 \% \\
24.64 \%\end{array}$ & $\begin{array}{c}4.8 \% \\
0 \%\end{array}$ & [109] \\
\hline
\end{tabular}


Risk factors related to toxoplasmosis and source of infection

Risk factors were studied in different parts of Saudi Arabia, but there is still a lack of information regarding the exact source of infection in different locations. The majority of the research studies in Saudi Arabia targeted women. Age as a risk factor detected in different areas, as shown in Table 6. According to a significant relationship between age and infection with $T$. gondii, different categories of age groups were found to be significant including $20-30$ years $30-40$ years, $40-84$ years, and 50-56 years. Resident in an urban area as a risk factor was recorded in two areas: AD-Dawadimi in the central and Rafha in the north. In contrast, resident in the rural area was detected in Al-Ahsa. Illiterate increased the infection with $T$. gondii found in one study in Al-Ahsa. In the same studies, researchers found that housewives and students and people in the lowest income were more appropriate for getting the infection. The race was detected to be significant with infection with $T$. gondii in one study in Makkah in blood donors.

Table 6. The risk factors increase the infection in different areas and different target groups.

\begin{tabular}{|c|c|c|c|c|c|c|}
\hline \multirow[b]{2}{*}{ City } & \multirow[b]{2}{*}{$\begin{array}{l}\text { Target } \\
\text { group }\end{array}$} & \multirow[b]{2}{*}{ Risk factor (s) } & \multicolumn{2}{|c|}{ ELISA } & \multirow[b]{2}{*}{$P$ - value } & \multirow[b]{2}{*}{ References } \\
\hline & & & $\begin{array}{c}\text { IgG } \\
\text { positive }(\%)\end{array}$ & $\begin{array}{c}\text { IgG } \\
\text { negative (\%) }\end{array}$ & & \\
\hline \multirow[t]{2}{*}{ AD-Dawadimi } & \multirow{2}{*}{$\begin{array}{l}\text { Pregnant } \\
\text { women }\end{array}$} & Resident in urban & $129(46.5 \%)$ & $148(53.5 \%)$ & 0.001 & {$[78]$} \\
\hline & & Age group $\geq 41$ years & $4(57.1 \%)$ & $3(42.9 \%)$ & 0.048 & {$[80]$} \\
\hline \multirow{2}{*}{$\begin{array}{l}\text { Khamis Mushait and } \\
\text { Abha }\end{array}$} & \multirow{2}{*}{$\begin{array}{l}\text { Pregnant } \\
\text { women }\end{array}$} & \multirow{2}{*}{$\begin{array}{c}\text { Increased number of pregnancies } \geq 5 \\
\text { increased number of parity number of } \\
\text { parity } \geq 5\end{array}$} & $67(46.2 \%)$ & $78(53.8 \%)$ & 0.05 & {$[80]$} \\
\hline & & & $29(44.6 \%)$ & $36(55.4 \%)$ & 0.46 & {$[80]$} \\
\hline \multirow{2}{*}{ Makkah } & \multirow{3}{*}{$\begin{array}{l}\text { Pregnant } \\
\text { women }\end{array}$} & Age group 50-65 years & $20(54 \%)$ & $17(46 \%)$ & 0.04 & \multirow{2}{*}[84]{} \\
\hline & & Contact with cat & $35(50.0 \%)$ & $35(50.0 \%)$ & 0.015 & \\
\hline \multirow{8}{*}{ Al Ahsa } & & Age group 20-30 years & $147(72.1 \%)$ & $57(27.9 \%)$ & 0.001 & \multirow{8}{*}[90]{} \\
\hline & \multirow{7}{*}{$\begin{array}{l}\text { Pregnant } \\
\text { women }\end{array}$} & Rural area & $191(58.8 \%)$ & $134(41.2 \%)$ & 0.001 & \\
\hline & & illiterate women & $109(61.0 \%)$ & $70(39.0 \%)$ & 0.006 & \\
\hline & & Of parity $\geq 4$ & $172(60.8 \%)$ & $111(39.2 \%)$ & 0.001 & \\
\hline & & Housewives/ students & $236(57.1 \%)$ & $177(42.9 \%)$ & 0.001 & \\
\hline & & Lowest income & $102(57.3 \%)$ & $76(42.7 \%)$ & 0.001 & \\
\hline & & Undercooked/raw meat & $158(61.2 \%)$ & $100(38.8 \%)$ & 0.007 & \\
\hline & & $\begin{array}{l}\text { Unfavourable obstetric outcome } \\
\text { (abortion) }\end{array}$ & $201(72.8 \%)$ & 75 (27.2\%) & 0.001 & \\
\hline \multirow[b]{2}{*}{ Tabuk } & \multirow[b]{2}{*}{ Student } & Ownership of cat & $3(33.3 \%)$ & $6(66.7 \%)$ & 0.023 & \multirow[b]{2}{*}[92]{} \\
\hline & & $\begin{array}{c}\text { Consumption of raw, unwashed fruit } \\
\text { or vegetables }\end{array}$ & $10(19.3 \%)$ & $42(80.7 \%)$ & 0.007 & \\
\hline \multirow[t]{2}{*}{ Najran } & Women & $21-30$ years & $16(45.7 \%)$ & $19(54.3 \%)$ & 0.018 & \multirow[t]{2}{*}[94]{} \\
\hline & \multirow{3}{*}{$\begin{array}{l}\text { Blood } \\
\text { donors }\end{array}$} & $30-39$ years & $21(25.0 \%)$ & $63(75.0 \%)$ & 0.005 & \\
\hline \multirow[t]{2}{*}{ Makkah } & & Race & $9(52.9 \%)$ & $8(47.1 \%)$ & 0.001 & \multirow[t]{2}{*}[97]{} \\
\hline & & Gardening & $22(36.7 \%)$ & $38(63.3 \%)$ & 0.0001 & \\
\hline \multirow[t]{6}{*}{ Rafha } & \multirow[t]{6}{*}{ Women } & $>30$ years & $11(19.0 \%)$ & $48(81.0 \%)$ & 0.038 & [99] \\
\hline & & $36-40$ years & $20(24.1 \%)$ & $63(74.9 \%)$ & 0.019 & \\
\hline & & Residence (urban ) & $51(13.0 \%)$ & $337(87.0 \%)$ & 0.0001 & \\
\hline & & Gravidity (grand multigravida) & $44(22.8 \%)$ & $149(77.2 \%)$ & 0.002 & \\
\hline & & Abortion history & $44(43.6 \%)$ & $57(57.4 \%)$ & 0.0001 & \\
\hline & & Still birth & $62(13.0 \%)$ & $414(87.0 \%)$ & 0.001 & \\
\hline Rafha & Women & Direct contact with cat & $17(25.4 \%)$ & $50(74.6 \%)$ & 0.007 & {$[100]$} \\
\hline & & Keeping indoor cat & $40(29.4 \%)$ & $96(70.6 \%)$ & 0.0001 & \\
\hline & & Cleaning cat area & $51(19.6)$ & $209(80.4 \%)$ & 0.001 & \\
\hline & & Contact with soil & $67(17.6 \%)$ & $313(82.4 \%)$ & 0.001 & \\
\hline & & Cleaning house dust & $71(16.8 \%)$ & $352(83.2 \%)$ & 0.002 & \\
\hline & & Eating soil (mud) & $25(21.9 \%)$ & $89(78.1 \%)$ & 0.01 & \\
\hline Qassim & $\begin{array}{l}\text { Cancer } \\
\text { patients }\end{array}$ & $40-84$ years & $30(71.4 \%)$ & $34(35.8 \%)$ & 0.001 & [103] \\
\hline & Diabetic & $50-56$ years & $20(54.1 \%)$ & $17(54.9 \%)$ & 0.04 & [105] \\
\hline маккап & patients & Contact cat & $35(50.0 \%)$ & $35(50.0 \%)$ & 0.015 & [100] \\
\hline Jeddah & Women & Infertility & $15(18.1 \%)$ & $68(81.9 \%)$ & 0.01 & [110] \\
\hline
\end{tabular}


The relationship between the increased number of pregnancies and an increased number of parity found to be increased the opportunity to get an infection with $T$. gondii. The correlation between infection with $T$. gondii and abortion, stillbirth, and infertility were detected.

Contact with cat or ownership cat as a risk factor to get an infection with $T$. gondii recorded in four different studies, as shown in Table 6. Consumption of raw or undercooked meat or raw fruits or vegetables were also observed. Also, contact with soil or eating mud as a risk factor to get an infection with $T$. gondii was found, as shown in Table 6.

\section{Molecular detection of toxoplasmosis}

Detection was done in five studies using different types of PCR in different parts of Saudi Arabia from the north to the central areas and in the south. The sample size of the study ranged between 43-226 samples. The prevalence rate of toxoplasmosis by molecular technique was a range between $0.6 \%$ in Rafha and $41 \%$ in Asser, as shown in Table 7.

\section{Genotyping of toxoplasmosis in human}

Genotyping of toxoplasmosis was done in three different areas in Riyadh, Jazan, and Al Madinah. The sample size varied and ranged between 91-226 samples. The methods used were different types of PCR. One study in Jazan detected the only type I strain while the study in Riyadh found type II and III strains. In addition, in Al Madinah all the types of strains were found Table 8 .

\section{Seroprevalence of toxoplasmosis in animals}

The majority of the studies conducted in Riyadh, the capital, and a few studies were done in Najran, Al-Ahsa, Qassim, and the central area. The studies targeted

Table 7. Detection of the prevalence of T. gondii in Saudi Arabia using molecular techniques.

\begin{tabular}{lcccc}
\hline Region & No. of samples & Method & Prevalence rate & References \\
\hline Rafha & 162 & B1 and RE PCR & $0.62 \%$ & {$[99]$} \\
Riyadh & 203 & PCR & $22.2 \%$ & {$[110]$} \\
Jazan & 226 & PCR-RFLP & $3.5 \%$ & {$[81]$} \\
Aseer & 137 & PCR & $41 \%$ & {$[82]$} \\
Jeddah & 43 & PCR & $37.2 \%$ & {$[106]$}
\end{tabular}

Table 8. Genotyping of $T$. gondii in Saudi Arabia.

\begin{tabular}{|c|c|c|c|c|}
\hline Region & No. of samples & Method & Type of strain & References \\
\hline Riyadh & 203 & Nested-PCR & $\begin{array}{l}\text { Type II }(80.6 \%) \\
\text { Type III }(19.4 \%)\end{array}$ & {$[110]$} \\
\hline Jazan & 226 & PCR-RFLP & Type I $(100 \%)$ & [81] \\
\hline Al Madinah & 91 & RFLP & $\begin{array}{c}\text { Type II }(45.1 \%) \\
\text { Type I and III }(20.9 \%)\end{array}$ & [111] \\
\hline
\end{tabular}

Table 9. Prevalence of T. gondii infection in different kind of animals in Saudi Arabia.

\begin{tabular}{|c|c|c|c|c|c|c|}
\hline Region & Type of animals & $\begin{array}{l}\text { Sample } \\
\text { size }\end{array}$ & Assay & $\begin{array}{c}\text { Prevalence rate } \\
\text { IgG \% }\end{array}$ & $\begin{array}{c}\text { Prevalence rate } \\
\text { IgM \% }\end{array}$ & References \\
\hline Najran & Sheep, goats and camels & 236 & IHAT and ELISA & $22.4 \%$ & $19.0 \%$ & [112] \\
\hline Riyadh & Camels & 412 & IFAT & $\begin{array}{l}13 \% \text { total } \\
\text { antibodies }\end{array}$ & - & [113] \\
\hline Riyadh & Sheep & 291 & IHAT and ELISA & $68 \%$ & - & [114] \\
\hline Riyadh & Goats & 87 & IHAT and ELISA & $58.6 \%$ & - & [115] \\
\hline Al-Ahsa & $\begin{array}{l}\text { Cats, dogs, sheep, goats, } \\
\text { cattle, and camels }\end{array}$ & 1148 & ELISA & $21.4 \%$ & - & [116] \\
\hline Riyadh & Chicken & 200 & ELISA & $32 \%$ & - & [117] \\
\hline Riyadh & Rats & 200 & ELISA & - & $13.5 \%$ & [118] \\
\hline Qassim & Chicken & 244 & DAT & $\begin{array}{l}11.9 \% \text { total } \\
\text { antibodies }\end{array}$ & - & [119] \\
\hline Riyadh & Cats & 200 & ELISA & $26 \%$ & - & {$[120]$} \\
\hline Central & Camels & 713 & LAT & $\begin{array}{l}13 \% \text { total } \\
\text { antibodies }\end{array}$ & - & {$[121]$} \\
\hline Riyadh & Sheep, goats, and camels & 1628 & IFAT & $\begin{array}{l}34.6 \% \text { total } \\
\text { antibodies }\end{array}$ & - & {$[122]$} \\
\hline
\end{tabular}


ruminant animals included sheep, goats, and camels. One study aimed at cattle and other animals such as chicken, cat, dog, and rat. The majority of studies used the ELISA technique to detect IgG, and a few studies used IgM. The IgG seropositivity was high in sheep in Riyadh (68\%), and the IgM seropositivity was found in Najran (19\%) in sheep, goats, and camels. The prevalence was less in chicken in Qassim $(11.9 \%)$ as shown in Table 9.

\section{Discussion}

The main outcome obtained from the current article was to determine the national prevalence rate of toxoplasmosis in Saudi Arabia, according to previous studies. Thus, the result received approximated that; one-third of the population in Saudi Arabia had antibodies against $T$. gondii infection. That means twothirds of the people at risk of getting an infection by this parasite and one-third may suffer from a latent parasite reactivation. The researchers confirmed that about onethird of the people worldwide had been infected by $T$. gondii [62,63], resulting in the present study counterpart with this fact. Although the infection is subclinical and asymptomatic still, the risk is existing mainly in pregnant women, children, and immunocompromised individuals as the disease caused abortion in pregnant women and malformation in children and being fatal in immunocompromised individuals.

The results also showed that the IgG seropositivity would be higher in the south of the country, and gradually reduced towards the north. In the Al-Jouf region, there is no data published regarding the prevalence rate throughout the previous twenty years. However, the acute infection found higher in the eastern area, and less case was detected in the north area. The variation in infection rate by $T$. gondii was different according to climate change, including different humidity, varying temperatures, and the various areas [64]. A similar study was done in the same target group in Iran; the results were higher in Iran than in KSA $[65,66]$.

Reactivation of chronic T. gondii infection in HIVinfected persons is most often connected with encephalitis with focal neurological abnormalities, sometimes with fever, defects of the visual field, and defects of cerebellum function, with neuropsychiatric symptoms. The extra cerebral form can also occur, mostly presented as chorioretinitis with multifocal and bilateral lesions of the optic nerve [67]. Therefore, study the disease as an opportunistic infection is critical. Several studies done in Saudi Arabia targeted people suffer from different diseases such as cancer patients, AIDS patients, diabetic patients, people who are suffering from glucose-6-phosphate dehydrogenase deficiency, neuropsychiatric patients, and schizophrenia and major depressive disorder. The results showed that the IgG seropositivity found high in a patient suffering from different diseases, and the IgM seropositivity found higher in AIDS patients. The result was logic, as in AIDS patients; the immunity will be less than usual. Human immunodeficiency virus (HIV) infection encompasses an acute phase that lasts for months, followed by a clinically latent phase that typically lasts for a few years and, ultimately, by the collapse of the immune system that characterizes acquired immunodeficiency syndrome $[67,68]$.

Age as a risk factor to increase the infection with $T$. gondii was studied in several studies. In conclusion, there are contrasting results in different parts of the world. The main idea was that, the infection increased by time, people who live a long time will be more susceptible to get the infection. Moreover, these results showed that, the infection by T. gondii in Saudi Arabia could infect almost all people of all ages, although no results available regarding teenaged children. These results matched with several results published around the world [69-71].

Prevalence of $T$. gondii infection in rural and urban was recorded in Saudi Arabia; a similar result was found in Chile. They found a high prevalence rate in both rural and urban areas [72]. The results confirmed that people who live in urban or rural have the same chance of getting an infection.

The level of education can increase the infection with $T$. gondii; in the current study, uneducated people were more suspected than educated people. A similar result was detected in southern Brazil [73]. The result will help health educators when they establish an educational program to control the disease.

Unemployed people or housewives in this study were found more infected than others; the same result was also found in southern Brazil [73]. It was logical as unemployed people or housewives may be more exposed to the source of the infection.

Association between exposures to $T$. gondii and abortion, stillbirth, and infertility had noticed in several studies. Abortion happened in the severe infection with high virulence parasite and mainly in the first trimester of pregnancy [74,75].

The main risk factors knew increased $T$. gondii infection, including contact with a cat, eat raw or undercooked meat, and contact with soil. In Saudi 
Arabia, all these factors were detected in different places as risk factors.

Molecular techniques didn't become widespread as diagnostic or routine tests in Saudi Arabia. However, some research studies were done by using these techniques but, still we need more effort to establish these methods and transfer and settled the technology. In few genotyping studies done in Saudi Arabia, all the strains of $T$. gondii were recorded in different areas.

The prevalence of chronic $T$. gondii in sheep was higher in Saudi Arabia, and most of the people depend on their food from sheep meat (Kabssa). Bradyzoite of $T$. gondii latent in the muscles, this will be of high risk, particularly in insufficiently cooked meat.

\section{Conclusion}

The results obtained confirmed that the disease was found in Saudi Arabia, although the recent infection was not high but the disease was recorded in almost all the regions. The prevalence rate was not apparent in one region, where it needs to be screened and showed the important of the disease there. A research study should be conducted to determine the main source of infection in the country. The education program should be raised and should study the socioeconomical impact of the disease to the people in KSA.

The prevalence rate of the disease in animals was not clear enough and needed more study research at national level to explore the situation in different animals.

\section{References}

1. Tenter AM, Heckeroth AR, Weissb LM (2000) Toxoplasma gondii: from animals to humans. Int J Parasitol 30: 1217-1258.

2. Dubey JP, Lindsay DS, Speer CA (1998) Structures of Toxoplasma gondii tachyzoites, bradyzoites, and sporozoites and biology and development of tissue cysts. Clin Microbiol Rev 11: 267-299.

3. Weiss LM, Kim K (2011) Toxoplasma gondii: The model apicomplexan. perspectives and methods, $2^{\text {nd }}$ edition: London Academic Press 49 p.

4. Tonouhewa AB, Akpo Y, Sessou P, Adoligbe C, Yessinou E, Hounmanou YG, Assogba MN, Youssao I, Farougou S (2017) Toxoplasma gondii infection in meat animals from Africa: Systematic review and meta-analysis of sero-epidemiological studies. Vet World 10: 194-208.

5. Dubey JP, Jones JL (2008) Toxoplasma gondii infection in humans and animals in the United States. Int J Parasitol 38: 1257-1278.

6. Durlach RA, Kaufer F, Carral L, Hirt J (2003) Toxoplasmic lymphadenitis-clinical and serologic profile. Clin Microbiol Infect 9: 625-631.

7. Bhopale GM (2003) Pathogenesis of toxoplasmosis. Comp Immunol Microbiol Infect Dis 26: 213-222.
8. Hill DE, Chirukandoth S, Dubey JP (2005) Biology and epidemiology of Toxoplasma gondii in man and animals. Anim Health Res Rev 6: 41-61.

9. Chaudhry SA, Gad N, Koren G (2014) Toxoplasmosis and pregnancy. Can Fam Physician 60: 334-336.

10. Dubey JP (2009) Toxoplasmosis in sheep-the last 20 years. Vet Parasitol 7: 1-14.

11. Robert-Gangneux F, Dardé ML (2012) Epidemiology of and diagnostic strategies for toxoplasmosis. Clin Microbiol Rev 25: 264-296.

12. Jones JL, Kruszon-Moran D, Rivera HN, Price C, Wilkins PP (2014) Toxoplasma gondii seroprevalence in the United states 2009-2010 and comparison with the past two decades. Am J Trop Med Hyg 90: 1135-1139.

13. Kaul R, Chen P, Binder SR (2004) Detection of immunoglobulin $\mathrm{M}$ antibodies specific for Toxoplasma gondii with increased selectivity for recently acquired infections. J Clin Microbiol 42: 5705-5709.

14. Ertug S, Okyay P, Turkmen M, Yuksel H (2005) Seroprevalence and risk factors for toxoplasma infection among pregnant women in Aydin province, Turkey. BMC Public Health 5: 66.

15. World Health Organization (2013) Congenital toxoplasmosis. Available: https://www.who.int/bulletin/volumes/91/7/en/ Accessed. 7 July 2013

16. Flegr J, Prandota J, Sovičková M, Israili ZH (2014) Toxoplasmosis - a global threat. Correlation of latent toxoplasmosis with specific disease burden in a set of 88 countries. PLoS One 9: e90203.

17. Jones JL, Kruszon-Moran D, Sanders-Lewis K, Wilson M (2007) Toxoplasma gondii infection in the United States, 19992004, decline from the prior decade. Am J Trop Med Hyg 77: 405-410.

18. Jones JL (2010) Holland GN. Annual burden of ocular toxoplasmosis in the US. Am J Trop Med Hyg 82: 464-465.

19. Scallan E, Hoekstra RM, Angulo FJ, Tauxe RV, Widdowson MA, Roy SL, Jones JL, Griffin PM (2011) Foodborne illness acquired in the United States-major pathogens. Emerg Infect Dis 17: 7-15.

20. Pappas G, Roussos NFM (2009) Toxoplasmosis snapshots: Global status of Toxoplasma gondii seroprevalence and implications for pregnancy and congenital, toxoplasmosis Original Research Article. Int J Parasitol 3: 1385-1394.

21. Robert-Gangneuxa F, Dardéc M (2012) Epidemiology of and diagnostic strategies for toxoplasmosis. Clin Microbiol Rev 25: 264-296.

22. Nissapatorn V (2007) Toxoplasmosis: A silent threat in Southeast Asia. Res J Parasitol 2: 1-12.

23. Aqeely H, El-Gayar EK, Perveen Khan D, Najmi A, Alvi A,Bani I, Mahfouz MS, Abdalla SE, Elhassan IM (2014) Seroepidemiology of Toxoplasma gondii amongst pregnant women in Jazan Province, Saudi Arabia. J Trop Med 2014: 913950.

24. Shawky S, Soliman NK (2001) Going beyond the curriculum to promote medical education and practice in Saudi Arabia. Saudi Med J 22: 477-480.

25. Abu-Madi MA, Al-Molawi N, Behnke JM (2008) Seroprevalence and epidemiological correlates of Toxoplasma gondii infections among patients referred for hospital-based serological testing in Doha, Qatar. Parasit Vectors 1: 39.

26. Alsammani MA (2016) Sero-epidemiology and risk factors for Toxoplasma gondii among pregnant women in Arab and African countries. J Parasit Dis 40: 569-579. 
27. Halos L, Thébault A, Aubert D, Thomas M, Perret C, Geers R, Alliot A, Escotte-Binet S, Ajzenberg D, Dardé ML, Durand B, Boireau P, Villena I (2010) An innovative survey underlining the significant level of contamination by Toxoplasma gondii of ovine meat consumed in France. Int J Parasitol 40: 193-200.

28. Dubey JP, Rajendran C, Ferreira LR, Martins J, Kwok OC, Hill DE, Villena I, Zhou H, Su C, Jones JL (2011) High prevalence and genotypes of Toxoplasma gondii isolated from goats, from a retail meat store, destined for human consumption in the USA. Int J Parasitol 41: 827-833.

29. Al-Qurashi AR, Ghandour AM, Obeid OE, Al-Mulhim A, Makki SM (2001) Seroepidemiological study of Toxoplasma gondii infection in the human population in the Eastern region. Saudi Med J 22: 13-18.

30. Mohammad M, Ahmed S, Hussain A (2012) Seroprevalence of Toxoplasma gondii in couples in Ramadi City using enzyme linked immunosorbent assay (ELISA) Int J Med Med Sci 4: 55-59.

31. Elsheikha HM, Aboul-Dahab MA, Abdel Maboud AI, ElSherbini ET (2009) Prevalence and risk factors of Toxoplasma gondii antibodies in asymptomatic Egyptian blood donors. J Egypt Soc Parasitol 39: 351-361.

32. Sun X, Liu P, Song Y, Zhang S, Ren J (2006) Preventive medicine tribune. Br Med J 1: 675-676.

33. Jones JL, Kruszon-Moran D, Rivera HN, Price C, Wilkins PP (2014) Toxoplasma gondii seroprevalence in the United States 2009-2010 and comparison with the past two decades. Am J Trop Med Hyg 90: 1135-1139.

34. Jones JL, Kruszon-Moran D, Sanders-Lewis K, Wilson M (2007) Toxoplasma gondii infection in the United States, 1999-2004, decline from the prior decade. Am J Trop Med Hyg 77: 405-410.

35. Hofhuis A, van Pelt W, van Duynhoven YT, Nijhuis CD, Mollema L, van der Klis FR, Havelaar AH, Kortbeek LM (2011) Decreased prevalence and age-specific risk factors for Toxoplasma gondii IgG antibodies in The Netherlands between 1995/1996 and 2006/2007. Epidemiol Infect 139: 530-538.

36. Al-Nakib W, Ibrahim ME, Hathout H, Moussa MA, Deverajan LV, Thorburn H, Yousof AM (1983) Seroepidemiology of viral and toxoplasmal infections during pregnancy among Arab women of child-bearing age in Kuwait. Int $\mathbf{J}$ Epidemiol 12: 220-223.

37. Dar FK, Alkarmi T, Uduman S, Abdulrazzaq Y, Grundsell H, Hughes P (1997) Gestational and neonatal toxoplasmosis: regional seroprevalence in the United Arab Emirates. Eur J Epidemiol 13: 567-57.

38. Shawky S, Soliman NK (2001) Going beyond the curriculum to promote medical education and practice in Saudi Arabia. Saudi Med J 22: 477-480.

39. Bouhamdan SF, Bitar LK, Saghir HJ, Bayan A, Araj GF (2010) Seroprevalence of toxoplasma antibodies among individuals tested at hospitals and private laboratories in Beirut. J Med Liban 58: 8-11.

40. Barah FA (2011) Prevalence of $\operatorname{IgG}$ antibodies against Toxoplasma gondii among Syrian females of childbearing age. Saudi Med J 32: 531-53.

41. El Deeb HK, Salah-Eldin H, Khodeer S, Allah AA (2012) Prevalence of Toxoplasma gondii infection in antenatal population in Menoufia governorate, Egypt. Acta Trop 124: 185-191.

42. Tammam AE, Haridy MA, Abdellah AH, Ahmed SR, Fayed HM, Alsammani MA (2013) Seroepidemiology of Toxoplasma gondii. infection in women with first trimester spontaneous miscarriage in Qena governorate, Egypt. J Clin Diagn Res 7: 2870-2873.

43. Elnahas A, Gerais AS, Elbashir MI, Eldien ES, Adam I (2003) Toxoplasmosis in pregnant Sudanese women. Saudi Med J 24: 868-870.

44. Khalil M, A\Aziz A, Elrayah I (2013) Prevalence and risk factors for Toxoplasma gondii infection in humans from Khartoum State, Sudan. Int J Public Health Epidemiol 2: 6066.

45. Kassem HH, Morsy TA (1991) The prevalence of antitoxoplasma antibodies among pregnant women in Benghazi, (S.P.L.A.J.) Libya. J Egypt Soc Parasitol 21: 69-74.

46. Bouratbine A, Siala E, Chahed MK, Aoun K, Ben Ismail R (2001) Sero-epidemiologic profile of toxoplasmosis in Northern Tunisia. Parasite 8: 61-66.

47. Fakhfakh N, Kallel K, Ennigro S, Kaouech E, Belhadj S, Chaker E (2013) Risk factors for Toxoplasma gondii and immune status of pregnant women: cause and effect? Tunis Med 91: 188-190.

48. Hai-Xia W, Cheng H, Pei-Liang Y, David L, Hong-Juan P (2016) Relationship between cat contact and infection by Toxoplasma gondii in Humans: A metaanalysis. Comp Parasitol 83: 11-19.

49. Guo M, Dubey JP, Hill D, Buchanan RL, Gamble HR, Jones JL, Pradhan AK (2015) Prevalence and risk factors for Toxoplasma gondii infection in meat animals and meat products destined for human consumption. J Food Prot 78: 457-476.

50. Juránková J, Opsteegh M, Neumayerová H, Kovarcik K, Frencová A, Baláz V, Volf J, Koudela B (2013) Quantification of Toxoplasma gondii in tissue samples of experimentally infected goats by magnetic capture and real-time PCR. Vet Parasitol 193: 95-99.

51. Cenci-Goga BT, Rossitto PV, Sechi P, McCrindle CME, Cullorm JS (2011) Toxoplasma in animals, food, and humans: an old parasite of new concern. Foodborne Pathog Dis 8: 751762.

52. Mizani A, Alipour A, Sharif M, Sarvi S, Amouei A, Shokri A, Rahimi M, Abdollah Hosseini S, Daryani A (2017) Toxoplasmosis seroprevalence in Iranian women and risk factors of the disease: a systematic review and meta-analysis. Trop Med Health 45: 7.

53. Andiappan H, Nissapatorn V, Sawangjaroen N, Khaing S, Salibay CC, Cheung MMM, Dungca JZ, Chemoh W, Teng CX, Lau Y, Adenan NM (2014) Knowledge and practice on Toxoplasma infection in pregnant women from Malaysia, Philippines, and Thailand. Front Microbiol 5: 1-8

54. Daryani A, Sarvi S Aarabi M, Mizani A, Ahmadpour E, Shokri A (2014) Seroprevalence of Toxoplasma gondii in the Iranian general population: a systematic review and meta-analysis. Acta Trop137: 185-194.

55. Dubey JP, Jones JL (2008) Toxoplasma gondii infection in humans and animals in the United States. Int J Parasitol 38: $1257-1278$.

56. Dubey JP, Thulliez P (1993) Persistence of tissue cysts in edible tissues of cattle fed Toxoplasma gondii oocysts. Am J Vet Res 54: 270-273.

57. Abdel-Rahman MAM (2017) Toxoplasmosis in man and animals. Egypt J Chem Environ Health 3: 54-73.

58. Hussain MA, Stitt V, Szabo EA, Nelan B (2017) Toxoplasma gondii in the Food Supply. Pathogens 6: 21. 
59. Spencer BR (2009) Transfusion transmission of parasites. In: Simon TL, editor. Rossi's Principles of Transfusion Medicine. UK: Blackwell Publishing Ltd 760-772.

60. Karimi G, Mardni A, Zadsar M (2014) Toxoplasma and blood transfusion. Iran J Parasitol 9: 597-598.

61. Lange AE, Thyrian JR, Wetzka S, Flessa S, Hoffmann W, Zygmunt M, Fusch C, Lode HN, Heckmann M (2016) The impact of socioeconomic factors on the efficiency of voluntary toxoplasmosis screening during pregnancy: a population-based study. BMC Pregnancy Childbirth 16: 197.

62. Montoya JG and Liesenfeld O (2004) Toxoplasmosis. Lancet 363: 1965-1976.

63. Weiss LM and Dubey JP (2009) Toxoplasmosis: a history of clinical observations. Int J Parasitol 3: 895-901.

64. Yan C, Liang L, Zheng K, Zhu XQ (2016) Impact of environmental factors on the emergence, transmission and distribution of Toxoplasma gondii. Parasit Vectors 9: 137.

65. Borna S, Shariat M, Fallahi M, Janani L. (2013) Prevalence of immunity to toxoplasmosis among Iranian childbearing age women: Systematic review and meta-analysis. Iran J Reprod Med 11: 861-868.

66. Malary M, Hamzehgardeshi Z, Moosazadeh M, Afshari M, Ahmadi I, Moghaddasifar I, Kheradmand M (2018) Seroprevalence of Toxoplasma gondii infection among Iranian pregnant women: a systematic review and meta-analysis. East Mediterr Health J 24: 488-496.

67. Šimeková K, Nováková E, Rosol'anka R, Masná J, Antolová D (2019) Clinical course of opportunistic infections toxoplasmosis and cytomegalovirus infection in HIV-infected patients in Slovakia. Pathogens 8: 219.

68. World Health Organization (2019) Global Health Observatory (GHO) Data. HIV/AIDS. Available online: https: //www.who.int/hiv/data/en/ Accessed: 31 December 2019

69. Avelino MM, Júnior DC, de Parada JB, de Castro AN (2004) Risk factors for Toxoplasma gondii infection in women of childbearing age. Braz J Infect Dis 8: 164-174.

70. Gebremedhin EZ, Abebe AH, Tessema TS, Tullu KD, Medhin G, Vitale M, Di Marco V, Cox E, Dorny P (2013) Seroepidemiology of Toxoplasma gondii infection in women of child-bearing age in central Ethiopia. BMC Infect Dis 13: 101

71. Wilking H, Thamm M, Stark K, Aebischer T, Seeber F (2016) Prevalence, incidence estimations, and risk factors of Toxoplasma gondii infection in Germany: a representative, cross-sectional, serological study. Sci Rep 622551.

72. Munoz-Zanzi C, Campbell C, Berg S (2016) Seroepidemiology of toxoplasmosis in rural and urban communities from Los Rios Region, Chile. Infect Ecol Epidemiol 6: 1.

73. Mareze M, Benitez AdN, Brandão APD, Pinto-Ferreira F, Miura AC, Martins FDC, Caldart ET, Biondo AW, Freire RL, Mitsuka-Brengo R, Navarro IT (2019) Socioeconomic vulnerability associated to Toxoplasma gondii exposure in southern Brazil. PLoS ONE 14: e0212375.

74. El-Tantawy N, Taman A, Shalaby H (2014) Toxoplasmosis and female infertility: Is there a correlation? Am J Epidemiol Infect Dis 2: 29-32.

75. Kheirandish F, Ezatpour B, Fallahi Sh, Tarahi MJ, Hosseini P, Karimi Rouzbahani A, Seyyed Tabaei SJ, Akbari S (2019) Toxoplasma serology status and risk of miscarriage, a casecontrol study among women with a history of spontaneous abortion. Int J Fertil Steril 13: 184-189.
76. Almogren A (2011) Antenatal screening for Toxoplasma gondii infection at a tertiary care hospital in Riyadh, Saudi Arabia. Ann Saudi Med 31: 569-572.

77. Alghamdi J, Elamin MH, Alhabib S (2015) Prevalence and genotyping of Toxoplasma gondii among Saudi pregnant women in Saudi Arabia. Saudi Pharm J 24: 645-651.

78. Alanazi AD, Alyousif MS, Alomar SA, Alanazi IO, AL Mohammed HI (2017) Seroprevalence and risk factors of Toxoplasma gondii infection among pregnant women in ADDawadimi general hospital, Kingdom of Saudi Arabia. J Egypt Soc Parasitol 47: 355-362.

79. Sarah YA, Uzma AK, Asmaa IE (2014) Prevalence of seropositive toxoplasmosis in pregnant women in Hail Region. Int J Health Sci Res 4: 66-71.

80. Almushait MA, Bin Dajem SM, Elsherbiny NM, Eskandar MA, Al Azraqi TA, Makhlouf LM (2014) Seroprevalence and risk factors of Toxoplasma gondii infection among pregnant women in south western, Saudi Arabia. J Parasit Dis 38: 4-10.

81. Eida AM (2015) Direct genotyping of Toxoplasma gondii in blood samples from pregnant women in Jazan, Saudi Arabia. J Egypt Soc Parasitol 45: 603-608.

82. Bin Dajem SM, Almushait MA (2012) Detection of Toxoplasma gondii DNA by PCR in blood samples collected from pregnant Saudi women from Aseer region, Saudi Arabia. Ann Saudi Med 32: 507-512.

83. Imam A, Al-Mansour M (2015) Serologic Evidence of Toxoplasma gondii infection among pregnant females in Qassim Region, Saudi Arabia. Pak J Med Res 54: 84-86.

84. Khalil M, Bahathiq A, Degnah N, Basuni S, Mahdi A, Al Malki A, Babalghith A (2016) Detection of Toxoplasma gondii infection and associated risk factors among pregnant women in Makkah Al Mukarramah, Saudi Arabia. Asian Pac J Trop Dis 6: 113-119.

85. Imam NFA, Azzam EAA, Attia AA (2016) Seroprevalence of Toxoplasma gondii among pregnant women in Almadinah Almunawwarah KSA. J Taibah Univ Med Sc 11: 255-259.

86. Ghazi HO, Telmesanib AM, Mahomeda MF (2002) TORCH agents in pregnant Saudi women. Med Principles Pract 11: 180-182.

87. Al-Harthi SA, Jamjoom MB, Ghazi HO (2006) Seroprevalence of Toxoplasma gondii among pregnant women in Makkah, Saudi Arabia. Umm Al-Qura Univ J Sci Med Eng 18: 217 227.

88. Alanazia FIB, Hassan TMM, Alanazi WMF (2017) Seroprevalence of Toxoplasma gondii among pregnant Saudi woman in Arar, Northern borders province, Saudi Arabia. Kasr Al Ainy Med J 23: 104-108.

89. Al-Mulhim AA, Al-Qurashi, AM (2001) Sero-prevalence of toxoplasmosis in pregnant mothers and new born infants in eastern province, Saudi Arabia. J Fam Community Med 8: 4648.

90. AL Mohammad HI, Amin TT, Balaha MH, AL Moghannum MS (2010) Toxoplasmosis among the pregnant women attending a Saudi maternity hospital: seroprevalence and possible risk factors. Ann Trop Med Parasit 104: 493-504.

91. Ashankyty IM (2014) Seroprevalence of Toxoplasma gondii among pregnant women visiting maternity hospital in Hail, KSA. Life Sci 11: 355-359.

92. Alzaheb RA, Al-Amer O (2017) The seroprevalence and risk factors of toxoplasmosis among female undergraduate university students in Saudi Arabia. Oman Med J 32: 486-491.

93. Alqahtani J, Hassan MM (2012) Incidence of toxoplasmosis gondii in Najran Region. J Egypt Soc Parasitol 42: 253-260. 
94. El-Shahawy IS, Khalil MI, Bahnass MM (2014) Seroprevalence of Toxoplasma gondii in women in Najran City, Saudi Arabia. Saudi Med J 35: 1143-1146.

95. Eisa ZM, Agag A, Al-Dawsary MM, Eifan SA, Al-Sum BA (2013) Toxoplasmosis in women, men, infants and animals in Jazan district. Biosc Biotech Resea Asia 10: 205-211.

96. Alshehri EM, Atorje EO, Basaeed LF, Assiri WM, Elfayoumi RI, Talaky AM, Zaka HA (2015) Seropositivity and awareness of Toxoplasmosis among University students. J Adv Lab Res Biol 5: 68-71.

97. Khalil M, Zamzami H, Deqnah N, AL Malki A, Alzayer S, AlGethamy M, AL-Pakistani H, AL Harbi W (2019) Seroprevalence of Toxoplasma gondii infection in blood donors in Makkah AL Mukarramah. Asian J Epidemiol 12: 25 31.

98. Zaglool DA, El-Bali M, Faidah HS, Al-Harthi SA (2017) Toxoplasma gondii seroprevalence at a tertiary care hospital in Makkah, Saudi Arabia. J Adv Lab Res Biol 8: 36-40.

99. Ali A, Khalil M, Toulah F (2017) Prevalence of Toxoplasma gondii in women population of Rafha city, Saudia Arabia. Pakistan J Zool 49: 1039-1047.

100. Ahmedani EI, EL Agib AA, Khalil M, Ali A, ALrawili HM (2018) Prevalence of toxoplasmosis and associated risk factors in women in Northern Border area, Saudi Arabia. IJBPAS 7: 1247-1262.

101. Al Mohammad HI, Balaha MH, AminTT, El Damarany EE, Dwedar A (2010) The accuracy of IgG avidity for detection of acute toxoplasmosis among pregnant Saudi Wwmen. TAF Prev Med Bull 9: 7-14.

102. Al-Qurashi AR, Ghandour AM, Obied OE, Al-Mulhim A, Makki SM (2001) Seroepidemiological study of Toxoplasma gondii in the human population in the Eastern Region. Saudi Med J 22: 13-18.

103. Imam A, Al-Anzi FG, Al-Ghasham MA, Al-Suraikh MA, AlYahya AO, Rasheed Z (2017) Serologic evidence of Toxoplasma gondii infection among cancer patients. A prospective study from Qassim region, Saudi Arabia. Saudi Med J 38: 319-321.

104. Zaini RG, Ismail KA, Dahlawi H (2016) Seroprevalence of Toxoplasma gondii among AIDS patients in Saudi Arabia. World J AIDS 6: 81-86.

105. Khalil M, Baothman M, Alserhan F, Almunyif A, Alsharbe G, Samaren H, Deqnah N, AL Malki A, AL Harbi W (2018) Prevalence of Toxoplasma gondii infection in diabetic patients in Makkah AL Mukarramah, Saudi Arabia. Trop Biomed 35: 464-471.

106. Tonkal AMD (2008) PCR Versus ELISA in diagnosis of human toxoplasmosis in Jeddah, Saudi Arabia. J Egypt Soc Parasitol 38: 707- 714.

107. Zaki WM, Hofdi RY, Shebiley AA, Saadi ZA, Ageel AH (2016) Seroprevalence of Toxoplasma gondii infection and its associated risk factors in neuropychiatric patients in Jazan province, Saudi Arabia. J Egypt Soc Parsitol 46: 467-474.

108. Tabbara KF, Sharara NA, Al-Momen AK (2001) Toxoplasmosis in a group of glucose-6- phosphate dehydrogenase deficient patients. Saudi Med J 22: 330-332.

109. Al-Hussainya NH, Al-saedib AM, Al-lehaibib JH, Al-lehaibib YA, Al-Sehlib YM, Afifi MA (2015) Serological evidences link toxoplasmosis with schizophrenia and major depression disorder. J Microsc Ultrastruct 3: 148-153.

110. Alghamdi J, Elamin MH, Alhabib S (2016) Prevalence and genotyping of Toxoplasma gondii among Saudi pregnant women in Saudi Arabia. Saudi Pharm J 24: 645-651
111. Abd El-Aal AA, Habib FA, Sheikh B, Harak M, Shalaby SA (2010) Toxoplasma genotyping among infected human and animal hosts using PCR-Restriction Fragment Length Polymorphism: Study in Al-Madinah, Saudi Arabia. Inter J of Health Science 3: 309-311.

112. Bahnass MM, El-Shahawy IS, Fawzi EM (2015) Comparative analysis of toxoplasmosis in farm animals by indirect hemagglutination assay and enzyme linked immunosorbent assay. Alex J Vet Sci 46: 15-19.

113. AL-Anazi AD (2011) Prevalence of Neospora caninum and Toxoplasma gondii antibodies in sera from camels (Camelus dromedarius) in Riyadh province, Saudi Arabia. J Egypt Soc Parsitol 41: 245 - 250.

114. Hussein MF, Almufarrej SI, Aljumaah RS, Al-saiady MY, A gar Elnabi AR, Abu Zaid TS (2011) Serological prevalence of Toxoplasma gondii and its association with abortion in sheep in Saudi Arabia. Acta Veterinaria 61: 405-414.

115. Al-Mufarrej SI, Hussein MF, ALjumaah RS, Gar EL, Nabi AR (2011) Toxoplasmosis in goats in Riyadh, Saudi Arabia J Anim Vet Adv 10: 2779-2782.

116. Al-Mohammed HI (2011) Seroprevalence of Toxoplasma gondii infection in cats, dogs, and ruminant animals in Al-Ahsa area in Saudi Arabia. Research J Med Sci 5: 190-192.

117. Elamin MH (2014) Seroprevalence and molecular detection of Toxoplasma gondii infection among chicken (Gallus domesticus) in Riyadh region, Saudi Arabia. WULFENIA J 21: 30-37.

118. Elamin MH (2014) Genotyping of Toxoplasma gondii from rats (Rattus rattus) in Riyadh, Saudi Arabia. Korean J Parasitol 52: 257-261.

119. Al Nasr I, El-Ashram S, Huang S (2018) Seroprevalence and genotyping of Toxoplasma gondii from free-range chickens in Qassim, Saud Arabia. Jpn J Vet Res" 66: 113-117.

120. Mohammed OB, Omar OI, Elamin EA, Bushara HO, Omer SA, Alagaili AN (2019) Seroprevalence of Toxoplasma gondii in household and stray cats of Riyadh, Saudi Arabia. Vet Ital 55: 241-245.

121. AL-Anazi AD (2012) Antibodies in sera from camels (Camelus dromedarius) in western and southern regions of central province, Saudi Arabia. J Egypt Soc Parsitol 42: 659664.

122. AL-Anazi AD (2013) Determination of seropositivity for Toxoplasma gondii in sheep, goats, and camels slaughtered for food and human consumption in Riyadh municipal abattoirs, Saudi Arabia. J Egypt Soc Parsitol 43: 569-576

\section{Corresponding author}

Khalil Mohamed (PhD)

Epidemiology Department, Faculty of Public Health and Health Informatics

Umm Al-Qura University

El Ilm St. 21955, Makkah, Saudi Arabia

Phone: +966-12-5501000

Fax: +966-12-5506700

E.mail: kmismail@uqu.edu.sa

Conflict of interests: No conflict of interests is declared. 